\title{
REGULAR TEACHERS INSTRUCTIONAL APPROACHES TO TEACHING CHILDREN WITH SPECIAL NEEDS IN SELECTED BASIC SCHOOLS IN SUNYANI MUNICIPALITY, GHANA
}

\section{${ }^{1}$ Isaac Gyamfi Korang, ${ }^{2}$ Mary Ashelo Umbugadu}

\author{
${ }^{1}$ Department of Social Science Education, Catholic University College of Ghana, Ghana. \\ ${ }^{2}$ Department of Special Needs \& Rehabilitation Sciences, Federal University of Lafia. \\ Nigeria. ${ }^{2}$ maryumbugadu@gmail.com
}

Corresponding Author: ${ }^{1}$ spinal108@yahoo.com

(D) https://orcid.org/0000-0001-6957-7527

Received: $3^{\text {rd }}$ October, 2020; Revised:05 $5^{\text {th }}$ October, 2020; Accepted: $07^{\text {th }}$ October, 2020

\section{Introduction}

The regular classroom teacher needs to understand the uniqueness of every child and tailor the instructional process to meet the needs of all children.

Purpose: The purpose was to find out whether regular teachers in basic schools have the requisite knowledge about children with special needs in their classrooms. Again, it focused on the challenges related to available teaching and learning resources given to regular teachers in teaching children with special needs.

Methodology: The study adopted the cross-sectional survey. In all, forty (40) teachers who had children with special needs in their classrooms were conveniently selected from (10) public basic schools for the study. The instrument used was a four point-point Likert-scale questionnaire supported with an observation guide. Cronbach's Alpha was used to determine the reliability of the instruments with .71 index.

Results: The study revealed that majority of the teachers $(M=1.669, S D=0.414)$ do not haveadequate knowledge to handle children with special needs in their classrooms. Further, $(M=1.531, S D=0.485)$ of the teachers revealed that they did not use instructional strategies that meet the needs of children with special needs in their classrooms. This was confirmed by majority $(M=1.634, S D=0.476)$ of the teachers when they were observed in their teaching to augment findings of the questionnaire item that sought to find out the instructional strategies regular teachers use in teaching.

Recommendations: It is important to extend the course duration of pre-service teachers by the Colleges of Education, to have sufficient avenues for fieldwork or practical experiences about the learning needs of children with special needs.

Keywords: Basic schools, Instructional approaches, Regular teachers, Adaptations, Children with special needs.

Crossref korang, I. G., \& Umbugadu, M. A. (2020). Regular teachers instructional Cited-by approaches to teaching children with special needs in selected basic schools in Sunyani municipality, Ghana. Journal of Educational Research in Developing Areas, 1 (2), 112-126. https://doi.org/10.47434/JEREDA.1.2.2020.112.

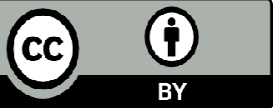

Copyright (c) 2020 The author(s) of this article retain(s) the copyright. 


\section{PUBLIC INTEREST STATEMENT}

This study focuses on the instructional approaches of regular teachers in basic schools who have children with special needs in their classrooms. There has been a policy shift to address the needs of all children in schools in Ghana particularly at the basic school level. This calls for teachers to be equipped with the requisite skills and knowledge to meet the learning of all children.The study would help stakeholders to identify the problems faced by teachers in teaching children with special needs and provide the available support for them in the form of seminars, workshops and inservice training with demonstrations.

\section{INTRODUCTION}

Ghana's effort to develop the potentialities of all children in the educational sector has resulted in the educational system to undergo changes over the years to provide policies and practices to meet the learning of all children. The Government of Ghana hoped of achieving full inclusion by 2015, recognized the obstacles in the implementation of the policy in terms of teacher preparedness and students participation in regular schools. The inclusive policy mentions the needs for schools to identify and see to the needs of children with disabilities by focusing on different learning and teaching strategies to ensure quality education (Ministry of Education, 2015). In spite of government policies to ensure access and education for all children, poor teacher attitudes and readiness towards children with disabilities serve as a great obstacle for full inclusion in Ghana. Avoke (2002) opines that negative attitude and persistent low regard for pupils with disabilities in schools cause a severe barrier to social and educational inclusion for children with disabilities in Ghana. Ntim (2013) stated that, children with some forms of disabilities and other category of children with special educational needs drop out of school. The reason being that these children have been denied their educational rights because of the instructional methods used by teachers in teaching them which they do not benefit. All children can learn when teaching is effective and meets individual strengths and learning needs. This calls for regular teachers to have the requisite knowledge about children with special needs to plan instructions to suit their learning needs in the instructional process. This study therefore focuses on Volume 1, Number 2 the regular teachers' knowledge in teaching children with special needs in regular classrooms at the basic level in the Sunyani municipality, Ghana.

Children with special educational needs form a momentous part of the overall school population and the concern for providing quality education for these children is key. In order for educational institutions and teachers to provide quality education to all children, there is the need for a better understanding about special educational needs. In the literature and in educational practice, the main attention of special needs has been given to the recognition of certain features seen as special needs and how these needs should be met (Vehmas, 2010). The concept of special educational needs is defined differently in various documents and is different across countries because they relate to each country's legislation. Hayford (2013) explains that there is a complexity involving the definition of special educational needs and classifications vary to an extent from one country to the other. To have a common and universal definition for special educational needs, Florian (2007) is of the view that, different terminologies are used in national contexts to explain special educational needs and there is a progressing struggle to find an acceptable definition for it.

In finding appropriate and suitable definitions to explain special educational needs, the Organization for Economic Cooperation and Development (OECD) (2012), reported that, special educational needs can cover a range of needs including physical or mental disabilities, and cognition or educational impairments. According the OECD, a child is recognised as having special 
educational needs when that child is not able to benefit from the school education made generally available for children of the same age without additional support or adaptations in the content of studies (p.1). According to National Council for Special Education (NCSE) (2014), children with special needs have much in common with other children of the same age. The NCSE further reports that there are many aspects to a child's development that make up the whole child including personality, the ability to communicate, resilience and strength and the ability to enjoy life and the desire to learn ( p.9). The Education for Persons with Special Needs (EPSEN) Act passed into law in July 2014 explained special educational needs as "a restriction in the capacity of the person to participate and benefit from education on account of an enduring physical, sensory, mental health or learning disability or any other condition which results in a person learning differently from a person without condition" (NCSE, 2014, p.14). In Ghana, children with special needs extend beyond those who may be included in disability categories to cover those who fail in school, as well as a wide range of reasons that are known to be barriers to a child's optimal development in learning (MOE, 2013). According to the Ministry of Education report, the various categories of persons with varied educational needs in Ghana include but not limited to persons with hearing impairment, persons with visual impairment, person with intellectual disability, persons with physical disability, person with deaf-blindness, children placed by natural catastrophes and social conflicts, nomadic children, children living in extreme social and economic deprivation, children for financial purpose, orphans, children with HIV/AIDS and children who are not living with their biological parents (p.6).

The education of all children within the general classroom brings about challenge for teachers. There is recognition that the challenges faced by the teaching profession are increasing as educational environments become more complex and heterogeneous (European
Parliament, 2008). The switch to inclusive education across the globe means that general education teachers who are not adequately prepared to teach children with disabilities, would undertake the overall responsibility of the education of children with special needs. Teachers' knowledge about children with special needs include: knowledge and experience of the characteristics of children with learning disabilities, the perception of learning materials that can be given, and the perception of appropriate intervention against the specific learning difficulties that were found (Rudiyarti, Pujaningsih \& Mumpuniarti, 2017). This calls regular teachers to have some level of professionalism in teaching children with disabilities in regular classrooms. The European Agency for Development in Special Needs Education (EADSNE) (2010) mentions that the basic process of teaching children with special needs in regular classroom is that regular classroom teachers have certain knowledge and understanding about the needs of different learners, teaching techniques and curriculum strategies. In the regular classroom, teachers meet children with varied needs and there is the need for teachers to teach to meet the needs of all the learners in the class. Lamport (2012) is of the view that, it is important teachers are equipped with the skills and strategies to support behaviour management of all children and to have the capability to differentiate instruction for students with special needs.

The success of teaching children in a class where children meet with diverse needs depends greatly on the teacher's ability to adapt instructions and vary teaching pedagogies to suit the needs of all children. Das, Kuyini and Desai (2013) in assessing the current skill levels of regular primary and secondary school teachers in Delhi, it resulted that that nearly seventy percent of the regular school teachers rated themselves not competent in the needed skills to teach children with special needs. For teachers to understand the careful selection of instructional method of delivery in teaching regular classrooms 
where children with special needs are found, Schulman (2005) cited WeiB, Kollmannsberger, Lerche, Oubaid and Kiel (2014) shared the view that teachers are to understand the dimensions by which instructions in the general classroom should be carried. They explained the dimensions to consist of concrete, operational acts of teaching and learning, of showing and demonstrating of questioning and answering. Florian and Spratt (2013) also shares the view that in a class where children meet with diverse needs, the teacher needs to understand and use an approach that requires a theoretical understanding of the ways that children learn. In planning lessons, teachers need to have in mind the different entering behaviour of all children in the classroom environment. This will enable children with special needs feel a sense of belongingness in the activities in the regular classroom. The individual, psychological and sociological conditions of learning must also to be considered when planning instruction to meet the needs of children (WeiB et al., 2014). Hallahan, Kaufmann, and Pullen (2012) also share this view that teachers should capture the initial learning situation, as well as competencies in the area of communication, behaviour, socialisation and emotion, perception and psychomotor performance, as well as the appraisal of development risks.

The knowledge of the teachers in selecting appropriate teaching strategies to meet the learning needs of all children will promote the understanding of concepts in a subject by children with special needs in the classroom. Rix, Sheehy, Fletcher-Campbel, Crisp and Harper (2013) share the view that the effective pedagogies for teaching children with special needs in regular classrooms depend upon the skills teachers have in understanding and responding to uniqueness of every child. Again, teachers are able to increase the participation of children with special needs by pairing them to work with others in the classroom environment. Peer tutoring must therefore be considered as a strategy by regular teachers to ensure active participation of children with special needs in the regular classroom. Lamport (2012) shares the view that, when students work together and are able to engage in discussions on different ideas, it means children with special needs can attain great success and transmit their knowledge to one another. Peer tutoring motivates learners and helps to improve their social and communication skills. Further, the classroom environment and its management are essential skills that the regular teacher needs to have to ensure all learners benefit from the teaching and learning process. The National Council for Special Education (2011) opines that classroom management and organisation in terms of layout, access to material, visual structure, schedules and predictability all contribute to a positive classroom experience for pupils. In the inclusive classroom, the regular teacher needs to understand that any decision he or she makes in the instruction process and in the learning environment is likely to affect the entire classroom needs.

Also, there is the need for teachers to support the assessment process by scrutinising the different stages of assessment and different needs of every individual in the classroom. Assessment in the inclusive classroom must be flexible vis-à-vis the mode of measurement to ensure equal opportunity for children to exhibit their competences. Waterfield and West (2010), refers to this as inclusive assessment which they defined as "a fair way of assessing for learning that achieves the objective of measuring the learning outcome of a course awarding grades, while recognising student diversity and different learning styles" (p.12). This helps to ensure equity evaluation in the teaching and learning process. The regular classroom teacher has a vital role to play in the process of teaching and learning and such roles must be a concern to help all children benefit from the teaching and learning process.

For effective teaching of children with special needs in the regular classroom, teachers must be provided 
with the necessary support and assistance. Stakeholders in education must understand that the teaching of children with diverse needs in the regular classroom is a complicated process. This calls for planning among the stakeholders to ensure that the teaching resources and needs of the teacher are met. Catholic Relief Service (2010) mentions that, to provide access to quality education of children with special needs in the regular classroom, barriers must be removed to create conditions to enable all children to learn. The CRS report, further explains that in poor countries, factors such as lack of available funding, administrative and policy level support and trained personnel pose challenges that slow down progress of teaching children with special needs in the general classroom. Teachers therefore need to be supported to gain experiences to remove barriers to the effective teaching of all children particularly the child with special needs. Opoku, Agbenyega, Mprah, Mckenzie, and Badu (2017) argue that teachers need to be provided with the required support and training which will enable them understand the use of different teaching techniques, strategies, styles and approaches needed to support the different abilities in the learning environment.

A report presented by the Catholic Relief Services on preparing teachers for inclusive education in Vietnam (2010) states that, teachers must be given inservice training from time to time in order to build effective human resources in the field of education, for teachers to be fully efficient to function effectively in their classrooms to meet the learning needs of all children. In order for regular teachers to have adequate knowledge about teaching children with diverse needs, training and seminars should be organised on regular basis to equip teachers with the adequate knowledge required to effectively teach children in the regular classroom. Engelbrecht (2013), mentions that teachers are not only required to be equipped with competencies but also the values and beliefs needed to achieve the goals of inclusive education systems which should be integrated into initial education as well as ongoing professional development. Teachers must be given the necessary training and support before they can adjust their ways of teaching to suit the needs of all children. Therefore, government needs to provide the schools with the resources and materials to aid the teaching of the varied needs in the regular classroom. Kuyini (2010) supports the idea of providing the necessary facilities for the implementation and practice of inclusive education to be effective. Further, families of children with disabilities in regular classrooms must also show corporation and work with teachers. Obeng-Asamoah (2016) stated that when family members show positive attitude towards their children with special needs, it helps regular teachers to collaborate with parents.

Most regular teachers at the basic schools who teach in classes where children who demand special education provision are found do not receive the needed resources to help them function effectively in the inclusive classroom. Das, Kuyini and Desai (2013) supports this assertion that nearly eighty seven percent of regular teachers in Delhi do not have access to support services in their classrooms. Teachers are again faced with challenges in dealing with large classes where children with special needs are found. On the challenges imposed on teachers by large class size, Gadagbui (2013) mentions that physical barriers are major challenges that teachers face in teaching children with special needs in the regular classrooms with inadequate textbooks as examples. The availability and use of teaching aids and learning materials affect teachers' preparedness and readiness for effective lessons. Gadagbui (2013), writing on class size and seating arrangements mentioned that the enrolment of regular and special schools in Ghana is abnormally large. The author explained further that the average number of pupils in a class must be between 8-15 pupils for the visually and hearing impaired but five and eight for mentally handicapped. Frimpong (2011) is also of the view that 
a teacher whether professional or not who has to work with too large a class would undoubtedly have his performance hindered and it will have a negative impact on students. Hayford (2013) explains that, the challenges faced by teachers include the inability to make time for the pupils, difficulty in marking class exercises and class control. This unpleasantly affect assessment of pupils as well as the quality of their marking. This increase in class size brings problems of ineffective class management, poor supervision of assignment and ineffective teaching and personal, pupils-teacher contacts.

\section{STATEMENT OF THE PROBLEM}

The education of all children to have equal access to education is seen as a right of every child of school going age regardless of his or her entering behaviour. According to the vision 2020 document of Ghana, ensuring that all citizens regardless of gender, disability, social status etc. are functionally literate and productive at the minimum is the ultimate goal of education. The education system will have the primary responsibility of providing means for the population to acquire the necessary skills to cope successfully in an increasingly competitive global economy (MOE, 2000). This calls for each child in the classroom to benefit from the teaching and learning process. However, children with some forms of disabilities and other category of children with special educational needs drop out of school with the reason that they have been denied their educational rights because of the instructional methods used by teachers in teaching them which they do not benefit (Ntim, 2013). This may be due to the inadequate basic professional skills needed by teachers to handle such children in their classrooms.

\section{PURPOSE OF THE STUDY}

find out:

The purpose of the study was to

1. whether regular teachers in basic schools in the Sunyani Municipality have the requisite knowledge about children with special needs in their classrooms.

2. the instructional adaptations regular teachers use to meet the learning needs of children with special needs.

3. the challenges related to available teaching and learning resources given to teachers in teaching children with special needs in regular classrooms in selected public basic schools in the Sunyani Municipality.

\section{RESEARCH QUESTIONS}

1. What knowledge do basic level regular teachers have about children with special needs in Sunyani municipality?

2. What instructional adaptations do basic level regular teachers use to meet the learning needs of children with special needs in Sunyani municipality?

3. What available teaching and learning resources do basic level regular teachers receive in teaching children with special needs?

\section{HYPOTHESIS}

1. There is no mean difference in gender with regard to teachers' knowledge to teaching children with special needs in Basic Schools in the Sunyani Municipality.

\section{METHODOLOGY \\ Research Design}

The cross- sectional survey design was selected for the study. Setia (2016) explains that, cross-sectional survey design is a type of observational study design where the investigator measures the outcome and the exposure in the study participants at the same time. Further, the study can be conducted relatively faster and are inexpensive. This design was adopted because it is the most popular form of survey designs in education and has the advantage of measuring current attitudes or practices and provides information in a short, for instance the time required for administering the survey and collecting the information (Creswel, 2014). 


\section{Population and sample}

The target population included all teachers in the 89 public Basic Schools in the Sunyani Municipality in the Bono region of Ghana. The sample size for the study was 40 teachers who agreed to have children with special needs in their class. Male teachers were 17 (42.5\%) and females 23 (57.5\%). More female regular teachers participated in the study. This confirms the general dominance of female teachers in most basic schools in Ghana. This is no exemption for regular teachers in the Sunyani Municipality selected for the study. The teachers were drawn from 10 public basic schools from the 6 circuits in the Sunyani Municipality. Convenience sampling technique was used to select the sample for the study.

\section{Table 1: Categories of children with special needs identified in the selected regular classrooms.}

\begin{tabular}{lccc}
\hline Disability & Frequency & Percentage (\%) & Cumulative Percent \\
\hline Visual Impairment & 6 & 9.8 & 9.8 \\
Physically Challenged & 12 & 19.7 & 29.5 \\
Hearing Impairment & 8 & 13.1 & 42.6 \\
Intellectual disability & 7 & 11.5 & 54.1 \\
Cerebral Palsy & 5 & 8.2 & 62.3 \\
Learning Disability & 18 & 29.5 & 91.8 \\
other & 5 & 8.2 & 100
\end{tabular}

The table depicts information on when regular teachers were asked to name the types of disabilities they had identified in their classrooms. The Table shows that 61 pupils were identified by the respondents to have some form of disabilities in the selected regular classrooms in basic schools in the Sunyani Municipality. From the Table, it is observed that 18 pupils representing $29.5 \%$ were pupils identified to have learning disabilities. 12 pupils (19.7\%) were pupils who are physically challenged. Again, 8 pupils $(13.1 \%)$ were pupils with hearing impairment and 7 pupils $(11.5 \%)$ were also pupils with intellectual disability. Pupils identified to be children with cerebral palsy were 5 representing $8.2 \%$. Finally, it was reported that 5 pupils $(8.2 \%)$ also had other forms of disability.

\section{Instrument for Data Collection}

The main instrument used to collect data for the study was a fourpoint Likert-scale structured questionnaire i.e. Strongly Agree, Agree, Disagree and Strongly Disagree, supported with an observation guide. The questionnaire consisted of twenty two items preceded by three factors that linked the topic. Each factor also consisted of statements carefully developed to link the factor. The factors included: regular teachers' knowledge about children with special needs ( 7 statements), instructional approaches of regular teachers in teaching children with special needs (10 statements) and the available teaching and learning resources regular teachers receive in teaching children with special needs (5 statements). Cronbach's Alpha was used to analyse the reliability of the instrument. Statistical reliability using the Cronbach's Alpha yielded .71.

\section{Procedure for Data Collection}

The questionnaire items were delivered personally by the researchers with the assistance of the Municipal Special Education Coordinator to the 40 teachers who served as respondents for the study. The selected teachers were reminded of the objectives of the study. After discussions with teachers in every 
school that the researchers visited, questionnaire items were given to participating teachers. The teachers were asked to complete the questionnaire items in a week's time. A period of two weeks was used to observe the teachers in their respective classrooms during teaching and learning sessions in English, Mathematics and Science. This was to collect additional information on the instructional adaptations used in teaching children with special needs by regular teachers.

\section{Method of Data Analysis}

For effective presentation and analysis of findings, the questionnaires were serially numbered to facilitate easy identification. Responses to the various items in the questionnaires were then added, tabulated and statistically analysed using the Statistical Package for the Social Sciences (SPSS). Responses to Likert scale items on a rating scale of Strongly Agree $(S A=4)$, Agree $(A=3)$, Disagree $(D=2)$, Strongly Disagree (SD) $=1$ was used. The statistical analysis used consisted mainly of frequencies and percentages. Ideas were classified through the use of tables where necessary to give it a pictorial and quick reference to the responses. An observation guide was designed by the researcher to observe the instructional strategies used by regular teachers to teach children with special needs. Teachers were observed according to the ratings of Very Good (VG) $=4$, Good $(G)$ 3 , Poor $(P)=2$ and Very Poor (VP).SPSS was again used to conduct Independent sample t-test to compare means and determine if a difference existed in the study between the mean of the knowledge regular teachers have in teaching with regard to gender, that is male and female teachers.

\section{RESULTS}

\section{Research Question 1}

What knowledge do basic level regular teachers have about children with special needs in Sunyani municipality?

\section{Table 2: Percentage, mean and standard deviation of knowledge of regular teachers in teaching children with disabilities in regular classrooms}

\begin{tabular}{|c|c|c|c|c|c|c|}
\hline \multirow[t]{2}{*}{ STATEMENT } & \multicolumn{2}{|c|}{ AGREE } & \multicolumn{2}{|c|}{ DISAGREE } & \multirow[t]{2}{*}{ MEAN } & \multirow[t]{2}{*}{ SD } \\
\hline & f & $\%$ & f & $\%$ & & \\
\hline $\begin{array}{l}\text { I learned how to teach children } \\
\text { with special needs from my } \\
\text { initial teacher education programs. }\end{array}$ & 30 & 75 & 10 & 25 & 1.25 & .439 \\
\hline $\begin{array}{l}\text { I have been given in-service } \\
\text { Trainingon how to teach children } \\
\text { With disabilities }\end{array}$ & 9 & 22.5 & 31 & 77.5 & 1.78 & .423 \\
\hline $\begin{array}{l}\text { I have knowledge on how to identify } \\
\text { children with special needs in the } \\
\text { regular classroom. }\end{array}$ & 23 & 57.5 & 17 & 42.5 & 1.42 & .501 \\
\hline $\begin{array}{l}\text { The training received from initial } \\
\text { teacher education program has } \\
\text { exposed me to teaching all categories } \\
\text { of special needs children. }\end{array}$ & 14 & 35 & 26 & 65 & 1.65 & .483 \\
\hline $\begin{array}{l}\text { Training at initial teacher education } \\
\text { is adequate to teach children with } \\
\text { disabilities effectively. }\end{array}$ & 5 & 12.5 & 35 & 87.5 & 1.88 & .335 \\
\hline $\begin{array}{l}\text { I have enough practical skills to } \\
\text { teach all categories of children } \\
\text { with special needs. }\end{array}$ & 5 & 12.5 & 35 & 87.5 & 1.88 & .335 \\
\hline $\begin{array}{l}\text { My knowledge about children } \\
\text { with special needs is adequate to } \\
\text { teach children with disabilities }\end{array}$ & 7 & 17.5 & 33 & 82.5 & 1.82 & .385 \\
\hline
\end{tabular}

Volume 1, Number 2 
Table 2 represents the responses of teachers on the knowledge regular teachers have in teaching children with special needs in regular classrooms in the Sunyani municipality. Majority $(M=1.669$, $\mathrm{SD}=0.414$ ) of the teachers showed that regular teachers teaching children with disabilities in regular classrooms in the Sunyani municipality do not have the required knowledge to teach children with special needs. However, the minority $14(34.3 \%)$ of the respondents, agreed with the statement.

\section{Research Question 2}

What instructional adaptations do basic level regular teachers use to meet the learning needs of children with special needs in Sunyani municipality?

Table 3: Percentage, mean and standard deviation of instructional strategies regular teachers use to meet the learning needs of children with special needs

\begin{tabular}{|c|c|c|c|c|c|c|}
\hline \multirow[t]{2}{*}{ STATEMENT } & \multicolumn{2}{|c|}{ AGREE } & \multicolumn{2}{|c|}{ DISAGREE } & \multirow[t]{2}{*}{ MEAN } & \multirow[t]{2}{*}{ SD } \\
\hline & f & $\%$ & f & $\%$ & & \\
\hline $\begin{array}{l}\text { I consider the learning needs of } \\
\text { children with special needs when } \\
\text { planning lessons. }\end{array}$ & 17 & 42.5 & 23 & 57.5 & 1.58 & .501 \\
\hline $\begin{array}{l}\text { I give prompt answers to pupils } \\
\text { with special needs questions. }\end{array}$ & 18 & 45.0 & 22 & 55.0 & 1.55 & .504 \\
\hline $\begin{array}{l}\text { I modify assignment to the } \\
\text { functional level of children with } \\
\text { special needs. }\end{array}$ & 12 & 30 & 28 & 70 & 1.70 & .464 \\
\hline $\begin{array}{l}\text { I organize seating arrangements } \\
\text { to meet the learning needs of } \\
\text { children with special needs during } \\
\text { instruction. }\end{array}$ & 26 & 65 & 14 & 35 & 1.35 & .483 \\
\hline $\begin{array}{l}\text { I frequently use teaching and } \\
\text { learning materials that meet the } \\
\text { learning needs of children with } \\
\text { special needs in teaching }\end{array}$ & 9 & 22.5 & 31 & 77.5 & 1.78 & .423 \\
\hline $\begin{array}{l}\text { I involve children with special } \\
\text { needsin the teaching and learning } \\
\text { process. }\end{array}$ & 24 & 60 & 16 & 40 & 1.40 & .496 \\
\hline $\begin{array}{l}\text { I give children with special needs } \\
\text { more time in task completion. }\end{array}$ & 16 & 40 & 24 & 60 & 1.60 & .496 \\
\hline $\begin{array}{l}\text { I pair children with special needs } \\
\text { to children without special needs } \\
\text { in task completion. }\end{array}$ & 21 & 52.5 & 19 & 47.5 & 1.48 & .506 \\
\hline $\begin{array}{l}\text { I give individual attention regularly } \\
\text { to children with special needs } \\
\text { during teaching. }\end{array}$ & 18 & 45.0 & 22 & 55.0 & 1.55 & .504 \\
\hline $\begin{array}{l}\text { I distribute questions fairly to } \\
\text { children with special needs. }\end{array}$ & 27 & 67.5 & 13 & 32.5 & 1.32 & .474 \\
\hline
\end{tabular}

The findings as shown in Table 3 reveals that $19(48 \%)$ of the teachers felt that they use instructional strategies to meet the learning needs of children with special needs in the regular classroom. However, the majority $(M=1.531, S D=$ 0.485 ) of the teachers disagreed with the statement. These results imply that regular teachers teaching children with special needs at the basic level in the Sunyani Municipality do not effectively use teaching strategies that meet the learning needs of children with special needs found in their classrooms.

Volume 1, Number 2 
Journal of Educational Research in Developing Areas (JEREDA)

Vol. 1. Issue 2, Pp. 112-126, 2020

http://www.jeredajournal.com

E-mail: info@jeredajournal.com

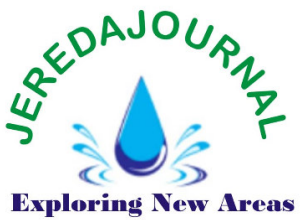

\section{Research Question 3}

What available teaching and learning

receive in teaching children with special resources do basic level regular teachers

needs?

Table 4: Percentage, mean and standard deviation of the available teaching and learning resources regular teachers receive

\begin{tabular}{|c|c|c|c|c|c|c|}
\hline \multirow[t]{2}{*}{ STATEMENT } & \multicolumn{2}{|c|}{ AGREE } & \multicolumn{2}{|c|}{ DISAGREE } & \multirow[t]{2}{*}{ MEAN } & \multirow[t]{2}{*}{ SD } \\
\hline & & $\%$ & & $\%$ & & \\
\hline $\begin{array}{l}\text { Parents collaborate withteacher } \\
\text { in the education of the child. }\end{array}$ & 16 & 40 & 24 & 60 & 1.60 & .496 \\
\hline $\begin{array}{l}\text { In-service training is provided } \\
\text { to teachers on how to teach } \\
\text { children with special needs }\end{array}$ & 7 & 17.5 & 33 & 82.5 & 1.82 & .385 \\
\hline $\begin{array}{l}\text { Teacher is assisted by resource } \\
\text { Personsin the regular classroom. }\end{array}$ & 2 & 5.0 & 38 & 95 & 1.95 & .221 \\
\hline $\begin{array}{l}\text { Teacher is provided with teaching } \\
\text { aidsthat suit childrenwith special } \\
\text { needs in the classroom. }\end{array}$ & 3 & 7.5 & 37 & 92.5 & 1.92 & .267 \\
\hline $\begin{array}{l}\text { School collaborates with teacher } \\
n \text { the teaching of children with } \\
\text { special needs. }\end{array}$ & 10 & 25 & 30 & 75 & 1.75 & .439 \\
\hline
\end{tabular}

It is evident from the data gathered that, almost all the regular teachers responded they do not receive the teaching and learning resources that enhance the teaching of children with special needs. This means 32 of the respondents which shows $(M=1.808$, $\mathrm{SD}=0.362$ ) disagreed to receive any form of support in their teaching.

\section{Hypothesis 1}

1. There is no mean difference in gender with regard to teachers' knowledge to teaching children with special needs in Basic Schools in the Sunyani Municipality.

Table 5: Independent sample t-test of male and female teachers and their knowledge in teaching children with disabilities

\begin{tabular}{lcccccc}
\hline $\begin{array}{l}\text { Gender of } \\
\text { participant }\end{array}$ & $\mathbf{N}$ & Mean & Std. Deviation & $\mathbf{t}$ & $\mathbf{d f}$ & P-value \\
\hline Male & 17 & 2.1765 & .38969 & & & \\
& & & & .424 & 38 & 0.674 \\
Female & 23 & 2.1180 & .45919 & & & \\
\hline$* \mathrm{P}>0.05^{*}$ & & & & &
\end{tabular}

The Table shows a no significant difference between the mean knowledge scores of male $(n=17, M=2.18$, Std. $D$ $=.39)$ and females $(n=23, M=2.12$, Std. $\mathrm{D}=.46)$. From the Table, since $p=$ $0.674>0.05$, the researchers rejects the Volume 1, Number 2 alternate hypothesis and maintains the null hypothesis and concludes that, there is no significant difference in gender with regard to teachers' knowledge to teaching children with special needs in Basic Schools in the Sunyani Municipality. 


\section{DISCUSSIONS}

From the data gathered, it was revealed that regular teachers teaching children with disabilities in regular classrooms in basic schools in the Sunyani municipality did not have adequate knowledge in teaching children with disabilities in regular classrooms. This is due to the fact that the questionnaire items measuring the knowledge regular teachers have in teaching children with special needs revealed that teachers did not have adequate knowledge to teach children with disabilities. This finding has confirmed other studies that, teachers lack the knowledge needed to be more effective at teaching and dealing with children who demand special education services and therefore, teachers should have adequate knowledge about the categories of children with special needs (Rudiyarti, Pujaningsih \& Mumpuniarti, 2017). The results is also consistent with the study of Dapudong (2014) that teachers have moderate knowledge in the education of special educational needs students in inclusive classrooms when he investigated international school teachers' knowledge and attitude towards inclusive education of special educational needs students in the Eastern seaboard region of Thailand in the school year of 2013-2014. Research indicates that it is essential for teachers to be trained to have the knowledge in the use skills and strategies needed to support behaviour management in the classroom and to have the ability to differentiate instruction for students with special needs (Lamport, 2012).

Again, results from the study revealed that teachers who participated in the study agreed to the statement that they learnt how to teach children with special needs in their initial teacher education programs. However, findings from the study showed a higher number of the teachers responding that training at initial teacher education is inadequate to teach children with special needs effectively. Literature shows that that Initial Teacher Training Institutions must make inclusive education compulsory subject for all teachers at the pre-service level (Catholic Relieve Services, 2010; Robinson, 2017). This calls for initial teacher training institution to train pre service teachers to have the prerequisite skills to handle children with heterogeneous needs in the learning environment.

Teachers' responses in the questionnaire and observation guide, revealed that majority of regular teachers at the basic level in the Sunyani Municipality did not adjust their teaching strategies to suit the learning needs of children who demanded special education services. This could have been as a result of the inadequate training teachers had about the teaching of children with special needs. This results from the study, is in conformance with the research by Das, Kuyini and Desai (2013) that the regular school teachers do not have competent skills to teach children with special needs. Again, the findings of the study confirm the views of Florian and Spratt (2013), teachers need to understand and use an approach that requires a theoretical understanding of the ways that children learn. This view is also supported by. Rix, Sheehy, FletcherCampbel, Crisp and Harper (2013) that the effective teaching methodologies required to teach children with special needs in regular classrooms is dependent on the teacher's skills in understanding and responding to differences. In this current study, teachers disagreed they consider the needs of children with special needs in planning instruction. Majority of the teachers reported that, they did not use teaching and learning materials that meet the learning needs of children with special needs. This action of the teachers did not contribute positively for children with special needs to benefit from the instructional process. The absence of this skill in regular teachers put them in a very difficult position to adapt instructional strategies to meet the needs of children with special needs.

The teaching of children with diverse needs in the regular classroom calls for the regular teacher to be given the needed resources to function effectively (Kuyini, 2010; Engelbrecht, 
2013; Opoku et al, 2017). It is evident from the findings that a greater number of regular teachers at the basic level in the Sunyani Municipality did not receive teaching and learning resources that enhance the teaching of children with special needs. This became clear, when teachers' views were sought to know the available teaching and learning resources they receive in teaching children special needs. The Support received by families of a child in school plays a vital role in the child's education. When family members show positive attitude towards their children with special needs, it helps regular teachers to collaborate with parents. (Obeng-Asamoah, 2016). Results from the study showed that majority of regular teachers affirmed that parents did not collaborate with them in the teaching and learning process. The ttest analysis revealed that there was no mean difference in gender with regard to teachers' knowledge to teaching children with special needs in Basic Schools in the Sunyani Municipality.

\section{CONCLUSION}

Based on the findings, the study showed regular teachers having children with special needs in their classrooms, did not have adequate knowledge needed to teach this category of learners in the regular classrooms. This implies that teachers are academically qualified but not professionally equipped to teach children with special needs effectively. This is due to the shallow nature of the course content at the initial teacher education program and the unavailability of regular in-service training and workshops organised for regular teachers. The analysis of the data from teachers' responses to the questionnaire and the results from the observation guide revealed that regular teachers at the basic level in the Sunyani Municipality did not adjust their teaching strategies to suit the learning needs of children who demanded special education services in the regular classroom. Further, the study shows majority of regular teacher at the basic level in the Sunyani Municipality did not receive support in terms of teaching and learning resources to enhance the teaching of children with special needs effectively. Large class size and inadequate time of instructional periods on the time table were challenges that did not help regular teachers to be able to fully involve and have adequate time for children with special needs in the regular classroom. This confirms the findings of (Frimpong, 2011; Gadagbui, 2013) that, physical barriers form a part of the challenges teachers face in teaching children with special needs in the regular classrooms which includes inadequate textbooks, large class size and seating arrangements.

\section{RECOMMENDATIONS}

The study revealed that regular teachers teaching children with special needs do not have adequate knowledge in teaching children with special needs; teachers do not get adequate practical experience on how to teach children at the pre-service level. Again teachers do not use instructional strategies that meet the learning needs of children with special needs in the regular classrooms. Based upon these:

1. The duration and course content of special education should be expanded to provide sufficient avenues for fieldwork or practical experiences about the learning needs of children with special needs for pre-service teachers before the completion of teacher education programmes.

2. Periodic seminars, workshops and inservice training should be organised for teachers to broaden their knowledge on contemporary trends about inclusive education practices.

3. Effective collaboration should exist between regular teachers and parents in the education of the child with special needs.

\section{Conflicts of Interest}

The authors declare no conflict of interest.

\section{Disclaimer Statement}

This article has been developed and written from the M.Ed. Dissertation work conducted in 2015 submitted to the School of Graduate Studies, University of 
Education, Winneba, Ghana, under the supervision of Professor Grace Yawo Gadagbui, University of Education, Winneba, Ghana.

\section{Notes on Authors \\ Isaac Gyamfi Korang is M.Ed. (Special Education) graduate from the University of Education, Winneba and currently an MPhil student at the Catholic University College of Ghana, Fiapre. He is a teacher at St. James Junior High School, Sunyani and a part time lecturer at University of Education, Winneba (IDeL) Sunyani. His study interest focuses on teacher preparation, students diversity and learning. He is alumnus of the Mandela Washington Fellowship for Young African Leaders who studied Civic Leadership at the University of Delaware, Newark DE, USA.}

Mary Ashelo Umbugadu is a certified educationist and a teacher. She is presently a lecturer with the Department of Special Needs Education and Rehabilitation Sciences, Federal University of Lafia, Nasarawa state, Nigeria. A member of the professional bodies of NAEC and NASET. Her hobbies are: reading and making friends.

\section{Authors' Level of Contributions \\ Isaac Gyamfi Korang wrote and compiled the manuscript and also administered the questionnaire.}

Mary Ashelo Umbugadu did the literature work for the study. Both authors developed the instruments and analysed the data collected for the study

\section{REFERENCES}

Avoke, M. (2002). Models of disability in the labelling and attitudinal discourse in Ghana. Disability and Society, 17(7), 769-777.

Catholic Relief Services (2010). How toguide services: Preparing teachers for inclusive Education. CRS Publishers.

Creswell, J. W. (2014). Research design: Qualitative, quantitative and mixed method approaches ( $\left.4^{\text {th }} \quad E d\right)$. Thousand Oak, CA Sage.
Dapudong, R, (2014). Teachers knowledge and attitude towards inclusive education: Basis for an enhanced professional development program. International Journal of Learning \& Development, 4 (4), 1-21.

Das, A. K., Kuyini., A. B. \& Desai I. P. (2013) Inclusive education in India: Are the teachers prepared? International Journal of Special Education, 28, (1), 27-36.

Engelbrecht, P. (2013). Teacher education for inclusion, international perspectives. European Journal of Special Needs Education, 28(2), 115-118.

European Agency for Development in Special Needs Education (2010). Teacher education for inclusion: International literature review. Retrieved on $10 / 07 / 2020$ from http://www.european-agency.org

European Agency for Development in Special Needs Education. (2012). Teacher education for inclusion project: Recommendations linked to sources of evidence. EADSNE.

European Parliament. (2008). European parliament resolution on improving the quality of teacher education. Retrieved from http://www.europarl.europa.eu/si des/getDoc.do?type $=$ TA\&reference $=$ P6-TA-2008-0422\&language $=$ EN.

Florian, L., \& Spratt, J. (2013). Enacting inclusion: A framework for interrogating inclusive practice. European Journal of Special Needs Education, 28 (2), 119-135.

Florian, L. (2007). The sage handbook of special education. Sage Publications Inc.

Frimpong, E. (2011). Factors contributing to poor performance of students in the basic education certificate examination in selected public junior high schools in Efutu Municipality. Unpublished thesis: University of Education, Winneba, Department of Special Education.

Gadagbui, G.Y. (2013). Exceptionalities, inclusive education, personality 
disorders \& gerontology.

Department of Education, University of Education, Winneba.

Hallahan, D. P., Kauffmann, J. M \& Pullen, P. C. (2012). Exceptional learners $12^{\text {th }}$ ed. Pearson.

Hayford, S. K. (2013). Special educational needs and quality education for all. University of Education Winneba.

Kuyini, A. B. (2010). Inclusive education in Ghana: Are we achieving the vision?

GhanaWeb.

https://www.ghanaweb.com/Ghan aHomePage/NewsArchive/Inclusive -EdcuationIn-Ghana-AreWeAchieving-The-Vision-179726.

Lamport, A. M. (2012). Special needs students in inclusive classrooms: The impact of social interaction on educational outcomes for learners with emotional and behavioral disabilities.

European Journal of Business and Social Sciences, 1 (5), 54-69.

Marczyk, G., DeMatteo, D. \& Festinger, D. (2005). Essentials of research design and methodology. John Wiley \& Sons.

Ministry of Education (2013). Draft: Inclusive education policy. http://www.voiceghana.org/downl oads/MoE IE Policy Final Draft1.p $\underline{\mathrm{df}}$

Ministry of Education (2015). Standards and guidelines for practice of inclusive education in Ghana.

http://sapghana.com/data/docume nts/InclusiveEducation-Policy-

Standards-Guidelines-officialdocument.pdf

National Council for Special Education (2014). Children with special educational needs. Information

Booklet for Parents. 1-2 Mill Street, Trim, Co Meath.

Ntim, S. (2013). The academic progression in paradox: Socio economic determinants of the mismatch between boys and the girl-child education in rural Ghana. International Journal of Humanities and Social Science, 3 (14), 178- 191.
Obeng-Asamoah, P., K. (2016, June 6). Ghana's policy on inclusive education: A tool for national development.

https://www.ghanaweb.com/Ghan aHomePage/features/Ghana-sPolicy-onInclusive-

Education-A-tool-for-nationaldevelopment-444807

Opoku, M. P., Aybenyega, J., Mprah, W. K., Mckenzie, J. \& Badu, E. (2017). Decade of inclusive education in Ghana. Journal of Social inclusion, 8 (1). 4-20. https://josi.journals.griffith.edu.au index.php/inclusion/article/downlo ad/956/84 7 .

Organization for Economic Cooperation and Development (2012). Social policy division-directorate of employment, labour and social affairs: Child well-being module. http://www.oecd.org/els/social/fa mily/database.

Rix, J., Sheehy, K., Fletcher-Campbel, F., Crisp, M. \& Harper, A. (2013). Exploring provision for children identified with special educational needs: An International review of Policy and Practice. European Journal of Special Needs Education, 28 (4), 375-391.

Rudiyati, S., Pujanininsih, P. \& Mumpuniarti, M. (2017), Teachers knowledge and experiences dealing with students with learning disabilities in inclusive elementary school. Advances in Social Science, Education and Humanities Research (ASSEHR), 66, 272-278.

Setia, M. E. (2016), methodology series module 3: Cross-sectional studies. Journal of Dermatology, 61(3), 261-264.

Vehmas, S. (2010), Special needs: A philosophical analysis. International Journal of Inclusive Education, 14 (1) ,87-96.

Waterfield, J., \& West, B. (2010). Diversity and inclusion: Programme assessment strategies. University of Plymouth. 
Journal of Educational Research in Developing Areas (JEREDA)

Vol. 1. Issue 2, Pp. 112-126, 2020

http://www.jeredajournal.com

E-mail: info@jeredajournal.com

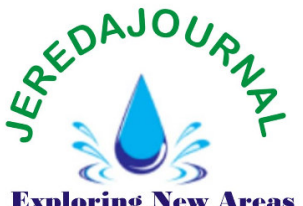

Exploring New Areas www.pass.brad.ac.uk/wp5inclusion . pdf

WeiB, S., Kollmannsberger, M., Lerche, T., Oubaid, V., \& Kiel, E. (2014).
The pedagogic Signature of Special Needs Education. European Journal of Special Education, 29(2), 200219. 